\title{
The Product Quality of Crab Meat (Portunus Pelagicus) Reviewing From Quality Improvement Of Occuptional Health And Safety (OHS) And Food Safety Productivity In PT. Bumi Menara Internusa
}

\author{
Dian Arisanti ${ }^{1}$, Soedarmanto ${ }^{2}$, Juli Prastyorini ${ }^{3}$, Yongky Siregar ${ }^{4}$ \\ Faculty of Administration and Management Barunawati, Surabaya Indonesia \\ \{dian.arisanti@stiamak.ac.id ${ }^{1}$,soedarmanto@stiamak.ac.id², juliprastyorini@stiamak.ac.id ${ }^{3}$ \}
}

\begin{abstract}
Improving the quality of Occuptional Health and Safety (OHS) and food safety productivity greatly affects the quality of the production of a product. Where product quality greatly affects consumer interest in buying a product. This study aims to analyze the quality of crab meat in terms of improving the quality of OHS and food safety productivity at PT. Bumi Menara Internusa. This study uses quantitative methods and data analysis techniques with multiple linear regression, where the sample used is all staff and employees as many as 45 respondents. Based on the analysis results, it can be concluded that the OHS Quality Improvement variable has the most dominant significant relationship with a beta value of 0.443 on the Quality of Results. The Food Safety Productivity variable has a significant relationship to the Quality of Results. Improving the Quality of OHS and Productivity of Food Safety simultaneously affects the Quality of Results. Where if the OHS Quality Improvement and Food Safety Productivity are given the better it will improve the quality of the crab meat products.
\end{abstract}

Keywords: Quality of Results, Quality Improvement of OHS, Productivity of Food Safety

\section{Preliminary}

Occupational Health and Safety (K3) in general in Indonesia often neglected. This is indicated by the high number of work accidents, even though employees are an important asset of the company. In carrying out a job, the issue of work safety and security is an important factor that must be the main concern of all parties (Achmad, 2009). Most of the cases of work accidents occur in the productive age group. Death is the result of a work accident that results in lifelong disability, in addition to having an impact on non-material losses, it also causes very large material losses, even greater than the costs incurred by sufferers of serious diseases such as heart disease and cancer (Novie, 2006).

Crayfish (Portunus pelagicus) is a fishery commodity that is currently in great demand in the international market (Sugeng et al., 2003). Crayfish are widely used for both the canning industry and direct consumption (BBPMHP, 2010). Meat crabs are exported in the form of frozen crabs without skin and heads and canned crabs that are pasteurized. Crab that has a soft texture and high protein content that makes it easy for friends to experience quality degradation. Some damage to fresh fishery products can occur by biochemically or microbiologically. Biochemical damage is caused by the presence of enzymes and biochemical reactions that are 
still taking place in the body of fresh fish. Meanwhile, microbiological damage is caused by microbial activity, especially bacteria (Hadiwiyoto, 2000). Canned minced meat using tin plate cans. Tin plate is a material used to make can packaging, consisting of steel sheet with tin coating. The advantages of tin plate are shiny, strong, rust-resistant and can be soldered. The most basic function of packaging is to contain and protect products from damage, making them easier to store, carry and market.

\section{Basic Theory}

According to Mondy (2008) work safety is the protection of employees from injuries caused by work-related accidents. Safety risks are aspects of the work environment that can cause fires, power lines, cuts, bruises, sprains, fractures, loss of organs, vision and hearing. While occupational health according to Mondy (2008) is freedom from physical violence.

Decree of the Minister of Manpower of the Republic of Indonesia No.463/MEN/1993, the benefits of occupational safety and health are to create a safe, healthy and prosperous society and work environment, so that it will be achieved : a safe, healthy and comfortable working environment with a healthy workforce physically, mentally, socially, and free from accidents. Will make the condition of an environment and employees will feel happy with the condition of the surrounding environment.

Muchtadi and Sugiyono (2003) stated that the content of carbohydrates, calcium, iron, phosphorus, vitamin A and vitamin B of the average crab and small crab were $14.1 \%, 210$ $\mathrm{mg} / 100 \mathrm{~g}, 1.1 \mathrm{mg} / 100$ respectively. g, $200 \mathrm{SI}$, and $0.05 \mathrm{mg} / 100 \mathrm{~g}$. According to Widhiastuti (2010), crab meat used as raw material for canning products sees several types based on their location on the crab body. Based on the location of crab meat as raw material for canning, it is divided into several parts, namely colossal and jumbo lump meat, dorsal fin, special, and claw meat.

\subsection{Productivity}

According to A. Bluchor and E. Kapustin in Hasibuan (1996), productivity is sometimes seen as an intensive use of the conversion of resources such as labor and machinery that is measured precisely and actually shows an appearance of efficiency.

\subsection{Implementation of Quality Management System}

The food industry as part of an industry based on agribusiness has a chain that involves many parties, ranging from primary producers - (transportation) - processors - distributors retailers - consumers. In each of these links, quality control (QC) is required due to the existence of Quality Assurance (QA) standards at the producer to consumer level, except for inspections at the transportation stage to achieve total quality control activities. or TQC) on aspects of design, production and productivity as well as marketing.

With different qualities, high quality (TQM) which is manifested in accordance with the demands of the ISO 9000 series (international quality certificates), namely ISO-9000 to ISO9004, and the latest is ISO 22000. HACCP is an aid to overcome the dangers that may occur in all production processes (starting from primary production to the hands of consumers). In other words, HACCP in Indonesia supports to ensure food safety.

\subsection{Review of Literature}




\section{Relationship between K3 Quality Improvement and Result Quality}

Improving the Quality of K3 has an important role in shaping the quality of the results. In a highly competitive market, companies must compete to provide satisfaction to their customers by improving the quality of the products produced.

\section{Relationship of Food Safety Productivity with Quality of Yield}

Quality is certainly an important thing because by providing quality products the company can certainly attract customers to buy the products being sold. For this reason, in order to get good quality production, the company must implement food safety productivity so that the products produced are in accordance with the food standards set by the company.

Relationship between K3 Quality Improvement and Food Safety Productivity with Quality Results

With the improvement of K3 quality and good food safety productivity will produce quality products, of course with quality products will be able to compete in local and international markets. The following is an overview of the framework of thinking in this research:

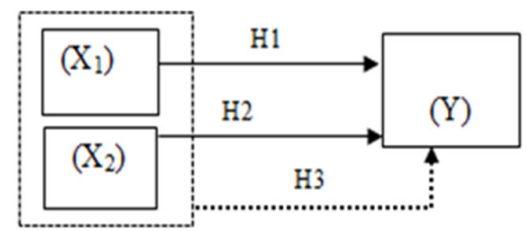

Fig 1. Framework of Thinking Source: Primary Processed

\section{Methodology}

This type of research approach is a quantitative type. The data analysis technique used multiple linear regression with data collection using a questionnaire. The population of this study were all staff and employees totaling 45 respondents. This research method is quantitative method and data analysis technique with multiple linear regression.

\section{Data Analysis Techniques}

Data analysis is the process of systematically searching and compiling data obtained from interviews, field notes, and documentation, by organizing the data into categories, breaking them down into units, synthesizing them, arranging them into patterns, choosing what is important and what is important. that will be studied and make conclusions so that they are easily understood by themselves and others (Sugiyono, 2011). The analysis technique used in this study is multiple linear regression analysis, by previously testing the quality of the data obtained by using validity and reliability tests. And using the classical assumption deviation test and hypothesis testing. 


\section{Data Analysis and Research Result}

\subsection{Data Testing}

\section{Validity Test and Reliability Test}

Based on data from questionnaires distributed to 45 respondents, it can be said to be valid or reliable if the instruments or indicators used in obtaining the data are valid or reliable. So it is necessary to test the validity and reliability test. The validity test was carried out using the Product Moment correlation coefficient method with a significant level of 0.05 while for the reliability test the Crobanch's Alpha method was used.

\section{Validity Test}

The validity test was carried out by looking at the $r$ count and $r$ table of each statement item which was carried out through the SPSS program. Each statement item is said to be valid if $r$ count $>$ rtable. The results of the validity test in this study of each statement item are as follows:

a. $\quad$ Test the Validity of the OHS Quality Improvement Variable (X1)

Results Based on data processing, the validity test of the OH\&S quality improvement variable $(\mathrm{X} 1)$ can be seen in the table below :

Table 1. Testing Results of Variable Validity of K3 Quality Improvement (X1)

\begin{tabular}{cccc}
\hline Statement Items & r-count & r-table & Description \\
\hline X1.1 & 0,778 & 0,294 & Valid \\
X1.2 & 0,927 & 0,294 & Valid \\
X1.3 & 0,939 & 0,294 & Valid \\
\hline
\end{tabular}

Source: Primary Processed Data with SPSS 16 (2021)

The variable for improving the quality of K3 consists of 3 statements. The correlation of each statement item has a calculated $r$ value greater than $r$ table so that based on the validity test shows that all statement items on the $\mathrm{k} 3$ quality improvement variable are declared valid and can be used as research instruments.

b. Validity Test of Food Safety Productivity Variables (X2)

Results Based on data processing, the validity test of the food safety productivity variable (X2) can be seen in the table below:

Table 2. Food Safety Productivity Variable Validity Test Results (X2)

\begin{tabular}{|l|l|l|l|}
\hline \multicolumn{1}{|c|}{$\begin{array}{c}\text { Statement } \\
\text { Items }\end{array}$} & r-count & r-table & Description \\
\hline $\mathrm{X} 2.1$ & 0,796 & 0,294 & Valid \\
\hline $\mathrm{X} 2.2$ & 0,632 & 0,294 & Valid \\
\hline $\mathrm{X} 2.3$ & 0,486 & 0,294 & Valid \\
\hline $\mathrm{X} 2.4$ & 0,730 & 0,294 & Valid \\
\hline $\mathrm{X} 2.5$ & 0,730 & 0,294 & Valid \\
\hline
\end{tabular}

Source: Primary Processed Data with SPSS 16 (2021)

The food safety productivity variable consists of 5 statement items. The correlation of each statement item has a calculated $r$ value greater than $r$ table so that based on the validity test shows that all statement items on service quality are declared valid and can be used as research instruments. 
c. Test the Validity of the Result Quality Variable (Y)

Based on the results of data processing, the validity test of the result quality variable (Y) can be seen in the table below:

Table 3 Test Results Validity Test Variable Quality Results (Y)

\begin{tabular}{|c|c|c|c|}
\hline $\begin{array}{l}\text { Statement } \\
\text { Items }\end{array}$ & r-count & r-table & Description \\
\hline Y.1 & 0,478 & 0,294 & Valid \\
\hline Y.2 & 0,709 & 0,294 & Valid \\
\hline Y.3 & 0,864 & 0,294 & Valid \\
\hline Y.4 & 0,860 & 0,294 & Valid \\
\hline
\end{tabular}

The result quality variable consists of 4 statement items. The correlation of each statement item has a calculated $r$ value greater than $r$ table so that based on the validity test shows that all statement items on the variable quality of results are declared valid and can be used as research instruments.

\section{Reliability Test}

To test the results (reliable) of a statement used Cronbach's Alpha analysis technique for each research variable through the SPSS program. The results of this test can be said to be reliable if Cronbach's Alpha >0.6 (Malhotra, 2012: 289). The results of the reliability test of the variables studied can be seen in the table below:

Table 4. Reliability Test Results

\begin{tabular}{lccc}
\hline \multicolumn{1}{c}{ Variable } & Cronbach's Alpha & Criteria & Description \\
\hline K3 Quality Improvement (X1 & 0,852 & 0.6 & Reliable \\
Food Safety (X2) & 0,641 & 0.6 & Reliable \\
Quality Result (Y) & 0,678 & 0.6 & Reliable \\
\hline
\end{tabular}

Source: Primary Processed Data with SPSS 16 (2021)

Based on table 5.4 it is known that the Cronbach's Alpha value of the variables of K3 Quality Improvement (X1), Food Safety Productivity (X2), and Quality of Results (Y) is greater than 0.6 so that it can be ascertained that the data is reliable, which means that the questionnaire can be used in research.

\section{Classical Assumption Test}

a. Normality test

Normality test is a test to determine the normality (normal or not) of the confounding factors et (error term). As it is known that these confounding factors have a normal distribution, so that a (partial) test can be carried out. To test the normality of the regression model, this study used the Normal P-P Plot of Regression Standardized Residual method. The basis for decision making is if the data spreads far from the diagonal line or does not follow the direction of the diagonal line, then the regression model does not meet the assumption of normality.

On the other hand, if the data do not spread far from the diagonal line or follow the direction of the diagonal line, then the regression model fulfills the normality assumption from the statistical results, as shown in the figure below: 

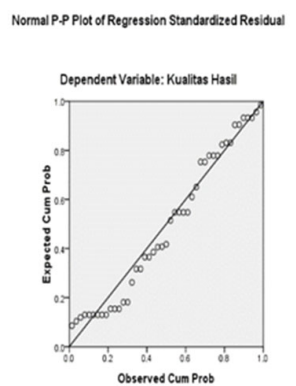

Fig 2. P-P Plot Normal Regression Standardized Residual Source: Primary Processed Data

In Picture 2, the results of the normality test on the graphic image show that the spread of data (points) on the diagonal axis of the graph does not spread far from the diagonal line or follows the direction of the diagonal line, so the regression model fulfills the assumption of normality.

In addition, it uses a graphical test that is equipped with statistical tests, one of which is the Kolmogorov-Smirnov non-parametric statistical test. If the significance value has a value $>$ 0.05 , it can be said that the residuals are normally distributed. The test results are presented in the following table:

Table 5. One-Sample Kolmogorov-Smirnov Test One-Sample Kolmogorov-Smirnov Test

\begin{tabular}{|ll|l|}
\hline & & $\begin{array}{l}\text { Unstandardized } \\
\text { Residual }\end{array}$ \\
\hline N & & 45 \\
Normal Parameters $^{\mathrm{a}}$ & .0000000 & .0000000 \\
& 1.50622218 & .41869694 \\
Most Extreme Differences & .135 & .161 \\
& .135 & .161 \\
& -.091 & -.112 \\
Kolmogorov-Smirnov Z & & .907 \\
Asymp. Sig. (2-tailed) & & .383 \\
\hline
\end{tabular}

Test distribution is Normal.

Source: Primary Processed Data with SPSS 16 (2021)

Table 5.4 above shows that the Kolmogorov-Smirnov $\mathrm{Z}$ value is 0.907 with a significance level of 0.383 , which means that the regression model is normally distributed because the significance level is $>0.05$.

\section{Multicollinearity Test}

The multicollinearity test was used to test whether the regression model found a correlation between the independent variables, namely improving the quality of k3 (X1) and food safety productivity (X2). Multicollinearity can be seen from the value of Tolerance and Variance Inflation Factor (VIF). If the value of Tolerance $<0.1$ or Variance Inflation Factor (VIF) $>10$, 
then multicollinearity occurs. If the Tolerance value $>0.1$ and the Variance Invlation Factor $(\mathrm{VIF})<10$, then there is no multicollinearity.

Table 6. Multicollinearity Test Results

\begin{tabular}{|l|l|l|l|}
\hline \multirow{2}{*}{ Model } & \multicolumn{2}{|c|}{ Collinearity Statistics } & Description \\
\cline { 2 - 4 } & Tolerance & VIF & \\
\hline $\mathrm{X}_{1}$ & 1,000 & 1,000 & Multicollinearity does not occur \\
\hline $\mathrm{X}_{2}$ & 1,000 & 1,000 & Multicollinearity does not occur \\
\hline \multicolumn{3}{|c}{ Source: Primary Processed Data with SPSS 16 (2021) }
\end{tabular}

Based on table 5.5 above, the tolerance value of the K3 quality improvement variable (X1) and food safety productivity (X2) which is 1,000 is greater than 0.10 . Meanwhile, the VIF value of the $\mathrm{k} 3$ quality improvement variable (X1) and food safety productivity (X2) which is 1000 is smaller than 10.00 so that it can be said that there is no multicollinearity.

\section{Heteroscedasticity Test}

The heteroscedasticity test aims to detect the occurrence of different relevant values of each independent variable, namely improving the quality of $\mathrm{k} 3$ (X1), food safety productivity (X2), in the model. The problem of heteroscedasticity in this study was detected using a scatterplot, namely by plotting the standardized predictor with the standardized residual model. If there is no clear pattern, and the points spread above and below the number 0 on the Y axis, then there is no heteroscedasticity. The following scatterplot results obtained from the SPSS output in the image below:

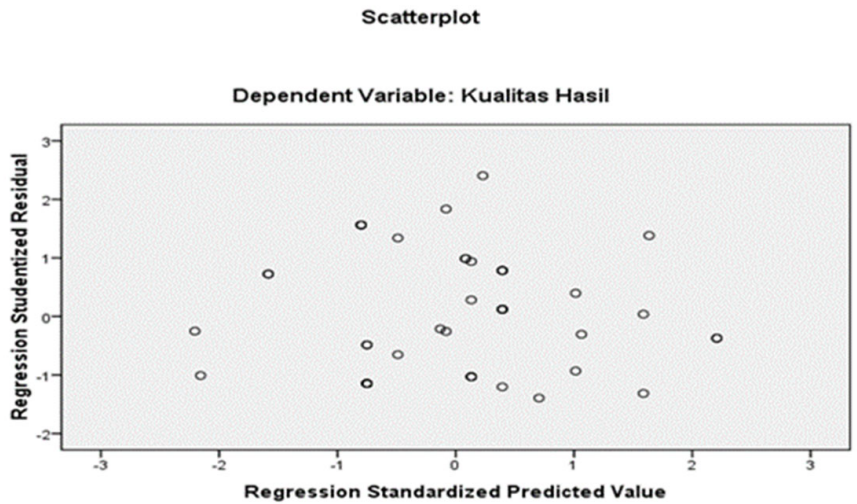

Fig 3. Heteroscedasticity Test

Source: primary data processed with SPSS 16 (2020)

In Picture 3, the results of the heteroscedasticity test in the image above show that the scatterplot does not form a certain pattern and the points spread above and below the number 0 on the $\mathrm{Y}$ axis, so there is no heteroscedasticity.

\section{Linearity Test}

The linearity test has a function to determine the form of the relationship between the independent variable and the specified variable. The basis for decision making in the linearity test is if the value of Sig. Deviation from linearity $>0.05$ then there is a linear relationship 
between the independent variable and the dependent variable, otherwise if the value of Sig. Deviation from linearity $<0.05$ then there is no linear relationship between the independent variable and the dependent variable. And here are the results of the linearity test:

Table 7. Linearity Test Results

\begin{tabular}{ccl}
\hline Variable & Sig. Deviation from linearity & \multicolumn{1}{c}{ Description } \\
\hline $\mathrm{X}_{1}-\mathrm{Y}$ & 0,456 & $\begin{array}{l}\text { There is a linear relationship between } \\
\text { improving the quality of K3 } \\
\text { and the quality of the results }\end{array}$ \\
$\mathrm{X}_{2}-\mathrm{Y}$ & 0,504 & $\begin{array}{l}\text { There is a linear relationship between } \\
\text { improving the quality of K3 } \\
\text { and the quality of the results }\end{array}$ \\
\hline
\end{tabular}

Source: primary data processed with SPSS 16 (2020)

Based on the test results above, it can be said that there is a linear relationship between the variables $\mathrm{X}$ and $\mathrm{Y}$.

\section{Multiple Linear Regression Analysis}

Regression analysis is used to determine the extent of the relationship between the independent variables to the specified variables. Based on regression analysis using SPSS, the following results were obtained :

\begin{tabular}{|c|c|c|c|c|c|c|}
\hline \multirow{2}{*}{\multicolumn{2}{|c|}{ Model }} & \multicolumn{2}{|c|}{$\begin{array}{l}\text { Unstandardized } \\
\text { Coefficients }\end{array}$} & \multirow{3}{*}{$\begin{array}{l}\text { Standardized } \\
\text { Coefficients } \\
\text { Beta }\end{array}$} & \multirow{3}{*}{\begin{tabular}{|l}
$\mathrm{t}$ \\
1.709
\end{tabular}} & \multirow{3}{*}{$\begin{array}{l}\text { Sig. } \\
.095\end{array}$} \\
\hline & & \multirow{2}{*}{$\begin{array}{l}\mathrm{B} \\
4.470\end{array}$} & \multirow{2}{*}{\begin{tabular}{|l|}
$\begin{array}{l}\text { Std. } \\
\text { Error }\end{array}$ \\
2.615 \\
\end{tabular}} & & & \\
\hline \multirow[t]{3}{*}{1} & (Constant) & & & & & \\
\hline & \begin{tabular}{|l} 
K3 Quality \\
Improvement
\end{tabular} & .541 & .160 & .443 & 3.386 & .002 \\
\hline & $\begin{array}{l}\text { Productivity } \\
\text { Security } \\
\text { Food }\end{array}$ & .293 & .132 & .291 & 2.223 & .032 \\
\hline \multicolumn{4}{|c|}{$\begin{array}{l}\text { a. Dependent Variable: Quality of } \\
\text { Results }\end{array}$} & & & \\
\hline
\end{tabular}

Source: primary data processed with SPSS 16 (2020)

$$
\begin{aligned}
& Y=\alpha+\beta_{1} X_{1}+\beta_{2} X_{2}+e \\
& Y=4,470+0,541 X_{1}+0,293 X_{2}+e
\end{aligned}
$$

Information:

$\begin{array}{ll}\mathrm{Y} & =\text { Yield Quality } \\ \alpha & =\text { Constant } \\ \beta_{1} & =\text { OHS quality improvement regression coefficient }\end{array}$


$\beta_{2}$

$\mathrm{X}_{1} \quad=\mathrm{K} 3$ quality improvement

$\mathrm{X}_{2} \quad=$ Food safety productivity

e $\quad=$ Estimation error
$=$ Food safety productivity regression coefficient

From the results of multiple linear regression testing there are equations that show the regression coefficients of the two independent variables $\left(\beta_{1}, \beta_{2}\right)$ are positive $(+)$ this means that if the K3 quality improvement variable (X1), food safety productivity (X2) meets the quality of the results to be obtained. achieved is increasing, and vice versa if it is negative (-) this means that if the K3 quality improvement variable (X1), food safety productivity (X2) is met, the quality of the results will decrease.

From these equations it can be explained that:

a. When the value of the variable consisting of improving the quality of K3 (X1), food safety productivity (X2) has a value of zero, then the variable quality of yield (Y) will remain at 4.470 because the constant value shows a value of 4.470 .

b. The coefficient of improving the quality of K3 (X1) of 0.541 indicates that the variable of improving the quality of $\mathrm{K} 3$ (X1) has a positive relationship to the quality of the results. This means that every $1 \%$ increase in the $\mathrm{K} 3$ quality improvement variable, there will be an increase of 0.541 in the result quality variable.

c. The food safety productivity coefficient (X2) of 0.293 indicates that the food safety productivity variable (X2) has a positive relationship with the quality of the results. This means that every $1 \%$ increase in the food productivity variable, there will be an increase of 0.293 in the yield quality variable.

\section{Hypothesis Test}

a. F Test (Simultaneous)

This test is used to determine whether the independent variables in improving the quality of K3 (X1) and food safety productivity (X2) together (simultaneously) have a significant relationship to the dependent variable, namely the quality of results (Y). In decision making, the $\mathrm{F}$ test uses a comparison of the calculated $\mathrm{F}$ value with the $\mathrm{F}$ table, that is, if the calculated $\mathrm{F}$ value $>\mathrm{F}$ table, then the hypothesis is accepted. On the other hand, if the calculated $\mathrm{F}$ value $<$ $\mathrm{F}$ table, then it is rejected. In the F table using the formula: $\mathrm{F}$ table $=(\mathrm{k} ; \mathrm{n}-\mathrm{k})$, where " $\mathrm{k}$ " is the number of independent variables (independent variable or $\mathrm{X}$ ), while " $\mathrm{n}$ " is the number of respondents or research samples. The following are the results of the F (simultaneous) test:

Table 9. F-Test Calculation at Significance Level 0.05

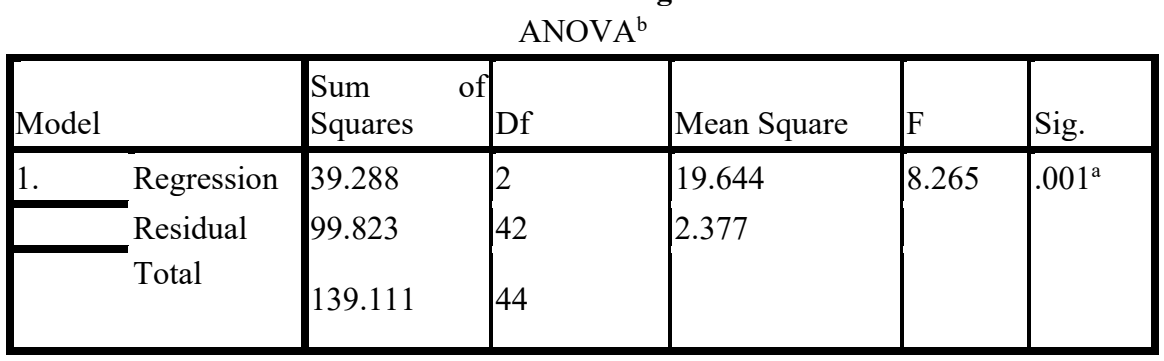

a. Predictors: (Constant), Food Safety Productivity, K3 Quality Improvement

b. Dependent Variable: Quality of Results

Source: primary data processed with SPSS 16 (2020) 
Based on table 5.8 above, it is known that improving the quality of K3 (X1) and food safety productivity (X2) together have a significant relationship to the dependent variable, namely the quality of the results (Y). This is evidenced by the significant value of $\mathrm{F}$ arithmetic 8.265 greater than $\mathrm{F}$ table 3.21 and a significance level of 0.001 smaller than alpha 0.05 .

b. $t$ test (Partial)

In displaying the $t$ table using the formula: $t$ table $=(0.025 ; n-k-1$ or df residual $)$ for the residual df value can be seen in table 5.8. Based on the results of the t-test with SPSS presented in table 5.8 above, it is known that the $\mathrm{K} 3$ quality improvement variable (X1) has a significant relationship to the quality of the results $(\mathrm{Y})$. This can be proven by the results of the $\mathrm{t}$-count of 3.386 which is greater than the t-table of 2.018 with a significance level of less than 0.05 . So it can be said that the variable of improving the quality of $\mathrm{K} 3$ has a significant relationship to the quality of the results partially.

\section{Multiple Coefficient of Determination Analysis}

The measurement of the coefficient of multiple determination aims to determine the magnitude of the correlation and relationship variables from the regression model in this study and to measure how close the estimated regression line is to the actual data. This can be seen through the coefficients $\mathrm{R}$ and $\mathrm{R}^{2}$. The results of the measurement of the correlation coefficient of this study can be seen in the following table:

Table 10. Calculation Results of $R$ and $R 2$. Coefficient Tests

\begin{tabular}{|l|l|l|l|l|}
\hline Model & $\mathrm{R}$ & R Square & $\begin{array}{l}\text { Adjusted } \\
\text { Square }\end{array}$ & Std. Error of the Estimate \\
\hline 1 & $.531^{\mathrm{a}}$ & .282 & .248 & 1.54167 \\
\hline
\end{tabular}

Source: primary data processed with SPSS 16 (2020)

From table 5.9 above, it is obtained that the $\mathrm{R}$ result is 0.531 which indicates that the relationship between the quality of the results with the variables of improving the quality of K 3 (X1) and food safety productivity (X2) is strong, because the R value is greater than 0.5 , it can be said to be strongly correlated. From the calculation of the coefficient of multiple determination with the help of SPSS, it is known that the value of the coefficient of double determination R Square is 0.282 or $28.2 \%$.

This value shows the results that have a relationship with the variables of improving the quality of $\mathrm{K} 3(\mathrm{X} 1)$ and food safety productivity (X2), the remaining $71.8 \%$ is related to other variables not examined in this study.

\section{Hypothesis Testing Determination of Dominant Influential Variables,}

Partial testing shows that all variables have a significant effect on customer loyalty. After it is known that the two independent variables have a partial effect, the next step is to make the dominant variable by looking at the "beta" value which has the highest value. The following are the results of testing the "beta" value on all research variables : 
Table 11 Beta Coefficient Value

\begin{tabular}{|l|l|}
\hline Variable & Standardized Coefficients (Beta) \\
\hline K3 Quality Improvement (X1) & 0,443 \\
\hline Food Safety Productivity (X2) & 0,291 \\
\hline
\end{tabular}

Source: primary data processed with SPSS 16 (2020)

From table 5.10 above, it shows that the highest beta value is the Food Safety Productivity (X2) variable of 0.443 .

\section{Discussion}

a. The relationship of improving the quality of K3 (X1) to the quality of the results (Y)

The independent variable partially has a significant relationship to the dependent variable. Based on the results of the t-test with SPSS presented in table 5.7 above, it is known that the K3 quality improvement variable (X1) has a significant relationship to the quality of the results (Y). This can be proven by the results of the t-count of 3.386 which is greater than the t-table of 2.018 with a significance level of 0.002 less than 0.05 . So it can be said that the K3 quality improvement variable has a significant relationship to the quality of the results partially. This explains that the improvement of $\mathrm{K} 3$ quality can produce quality products in accordance with established food safety quality standards.

b. The relationship between food safety productivity (X2) and product quality (Y)

The independent variable partially has a significant relationship to the dependent variable. Based on the results of the t-test with SPSS presented in table 5.7 above, it is known that the food safety productivity variable (X2) has a significant relationship to the quality of the results (Y). This can be proven by the results of the t-count of 2.223 which is greater than the $t$-table of 2.018 with a significance level of 0.032 which is less than 0.05 . So it can be said that the food safety productivity variable has a significant quality on the yield variable partially. This explains that the quality of the results is also very much determined by the productivity of food safety. Whereby implementing good food safety productivity can produce products that are safe for consumption and can compete with competitors.

c. The relationship between improving the quality of K3 (X1) and food safety productivity

(X2) on the quality of the results (Y)

It can be seen that the improvement of $\mathrm{K} 3$ quality (X1) and food safety productivity (X2) together has a significant relationship to the dependent variable, namely employee performance (Y). This is evidenced by the significant value of $\mathrm{F}$ arithmetic 8.265 greater than F table 3.21 and a significance level of 0.001 smaller than alpha 0.05 . K3 quality and food safety productivity carried out in accordance with well-defined standards will produce good and quality products so that they can be marketed to consumers in various regions.

\section{Conclusion}

The conclusions in this study are as follows:

a. The k3 quality improvement variable (X1) has a significant relationship to the quality of the results (Y). This can be proven by the t-count result of 3.386 which is greater than the t-table of 2.018 with a significance level of 0.002 less than 0.05 . This explains that if the improvement of K3 quality on the quality of crab meat products at PT. Bumi Menara Internusa is good, the results are also good. 
b. The food safety productivity variable (X2) has a significant relationship to the quality of the results $(\mathrm{Y})$. This can be proven by the $\mathrm{t}$-count result of 2.223 which is greater than the $\mathrm{t}$-table of 2.018 with a significance level of 0.032 which is smaller than 0.05 . This explains that the quality of the results is determined by the food safety productivity of PT. Bumi Menara Internusa.

c. The variables of improving the quality of K3 (X1), and food safety productivity (X2)

together (simultaneously) have a significant relationship to the variable quality of results (Y). This means that the better the improvement in the quality of $\mathrm{K} 3$ and the productivity of food safety provided, the higher the quality of the results. This is evidenced by the significance value of $\mathrm{F}$ arithmetic 8.265 greater than $\mathrm{F}$ table 3.21 and a significance level of 0.001 smaller than alpha 0.05 .

\section{Suggestion}

a. Improving the quality of $\mathrm{K} 3$ must be given more attention because it has a positive impact on the company by always checking regularly, especially in terms of maintaining good $\mathrm{K} 3$ equipment. If the improvement in the quality of $\mathrm{K} 3$ is getting better, it will have a very positive impact in the future. The quality of $\mathrm{K} 3$ must be improved by the entire board of directors, staff and all employees of PT. Bumi Menara Internusa, because by improving the quality of K3 it can reduce the possibility of bad work.

b. In producing a product, of course, it must be of quality, so that companies can produce quality products, of course there must be good food safety productivity, because an increase in good safety productivity will produce food products that can be consumed by the community. customer.

c. Activities to improve K3 quality and good work safety productivity can be carried out if all employees can carry out according to company standards, of course the company must also be able to provide work facilities so that company goals can be achieved.

\section{References}

[1] Achmad, Suaeb. 2009. Kesehatan dan Keselamatan Kerja. Jurnal Studi Kasus Teknologi Industri Universitas Gunadarma.

[2] Anoraga, Pandji.2005. PsikologiKerja. Jakarta: RinekaCipta.

[3] Badan Pusat Statistik (BPS). 2018. Data Ekspor - Impor 2012-2017. Badan Pusat Statistik. Jakarta

[4] Balai Bimbingan dan Pengujian Mutu Hasil Perikanan (BBPMHP), 2010, Laporan Pengembangan Pengolahan Kepiting Bakau dan Rajungan. Jakarta: Direktorat Jenderal Perikanan.

[5] Budiono, M. Sugeng.2003. BungaRampaiHiperkesdanKeselamatanKerja. Semarang: UNDIP.

[6] Direktorat Jenderal Penguatan Daya Saing Produk Kelautan dan Perikanan. 2018. Kinerja Ekspor Produk Perikanan Indonesia Tahun 2018. https://kkp.go.id/djpdspkp/artikel/7947-kinerja-eksporproduk-perikanan-indonesia-tahun-2018, diakses pada 27 Desember 2019.

[7] Ghozali, I 2011, Aplikasi Analisis Multivariete IBM SPSS 23, Badan Penerbit Universitas Diponegoro, Semarang.

[8] Ginting,Perdana.2007. SistemPengelolaanLingkungandanLimbahIndustri. Bandung: YramaWidya.

[9] Ibrahim, Jati Kusuma. 2010. Pelaksanaan Program Keselamatan dan Kesehatan Kerja Karyawan PT. Bitratek Industries Semarang. Jurnal Keselamatan Kerja.

[10] ISO-9001:2000. 2000. Quality Management Sistem. European Standard.

[11] Juwana,S.danKasijanRomimohtarto.2000.RajunganPerikanan,CaraBudidaya dan Menu Masakan. Jakarta: Djambatan.

[12] Kadarisman,D. 2000. Sistem Jaminan Mutu Pangan. Pelatihan Singkat Dalam Bidang Teknologi Pangan, Angkatan II. Kerjasama FATETA IPB - PAU Pangan \& GIZI IPB dengan Kantor Meneteri Negara Urusan Pangan/BULOG Sistem Jaminan Mutu Pangan, Bogor. 
[13] KhamidAbdul.

2018.BiologiRajungan

(Portunus

pelagicus)

http://perikanandaily.blogspot.com/2018/03/biologi-rajungan.html, diakses pada 20 Desember 2019.

[14] Kontan.2018.Ekspor Rajungan Berpotensi

Melesat.https://industri.kontan.co.id/news/ekspor-rajungan-berpotensi-melesat/,diakses pada 24 Desember2019.

[15] Malhotra, N.K. (2012). Basic Marketing Research : Integration of Social Media. Jakarta : PT Index Kelompok Gramedia.

[16] Mangkunegara, A. Prabu. 2005. Evaluasi Kinerja SDM. Bandung: RefikaAditama.

[17] Mondy, R.W., 2008, Manajemen Sumber Daya Manusia, Edisi Kesepuluh. Jakarta: Penerbit Erlangga.

[18] Novie, Mauliku. 2006. Jurnal Kajian Analisis Penerapan Sistem Manajemen K3 Di Rumah Sakit Immanuel Bandung.

[19] Pengertian metode https://ruangguru.co/pengertian-metode-penelitian/ diakses pada 1 juli 2020 pukul 08.14

[20] Ramadhan, Brigittadan Theodora. 2014. PengolahanLimbahCairdanPadat di IndustriPengolahanIkan. MakalahKunjunganPraktikumManajemenLimbahIndustriPerikanan. Yogyakarta: Universitas Gajah Mada.

[21] Ramli, Soehatman. 2010. Sistem Manajemen Keselamatan dan Kesehatan Kerja OHSAS 18001. Jakarta: Dian Rakyat.

[22] Sinungan, M. 2008. ProduktivitasApadanBagaimana. Jakarta: BumiAksara.

[23] Sugeng, Sapto P.R., Subiyanto, dan Hadi P. 2003. Budidaya Rajungan (Portunuspelagicus) di Tambak. Jepara: BBPBAP.

[24] Sugiyono. 2011. Metode Penelitian Kuantitatif, kualitatif dan R\&D. Bandung:

[25] Sugiyono.2013.http://rayendra.blogspot.com/2015/06/metode-penelitian-menurut-sugiyono2013.html Diaksespada 13 Desember 2019

[26] Suharsimi Arikunto. 2010. Prosedur Penelitian: Suatu Pendekatan Praktik. Jakarta: PT Rineka Cipta

[27] Suma'mur, P.K.2000. Higine Perusahaan danKeselamatanKerja. Jakarta: Haji Mas Agung.

[28] Suradi. 2005. Sistem Manajemen Keselamatan \& Kesehatan Kerja. Cetakan ke-1Jakarta Pusat. Argya Putra

[29] Tabel angka kecelakaan kerja https://hsepedia.com/wp-content/uploads/2018/12/Data-KasusKecelakaan-Kerja-di-Indonesia.png diakses pada 1 juli 2020 pukul 08.15

[30] Thaheer, H. 2005. SistemManajemen HACCP (Hazard Analysis Critical Control Point). Jakarta: BumiAksara.

[31] Widhiastuti, Indri. 2010. Analisis Rantai Pasokan Rajungan Studi Kasus PT. Windika Utama Semarang, Jawa Tengah. Bogor: Institut Pertanian Bogor.

[32] Winarno. F. G dan Surono. 2005. HACCP dan Penerapannya Dalam Industri. Jakarta:M-BrioPress. 